\title{
Civic Engagement of Christian Women in Pakistan
}

\author{
Tansif ur Rehman \\ University of Karachi, PAKISTAN \\ Faculty of Social Sciences, Department of Criminology
}

Received 13 December 2018 - Revised 25 May 2019 • Accepted 9 June 2019

\begin{abstract}
In Pakistan, which is an ideological state, the minority issue is sociological, as well as legal at the same time. Christians are the largest religious minority in Pakistan, but at all levels are facing discrimination, i.e. in socioeconomic, as well as politico-legal sphere. They are considered as a second-class citizen by masses. While the women who belong to this minority group are facing double discrimination, firstly as a woman, and then as a Christian. Interview schedule was used to collect data from the respective respondents. It is an exploratory research which was conducted in Essa Nagri (Karachi), which is one of the oldest residential areas of the city, and represents one of the largest population of Christian minority in Pakistan, i.e. around 40,00o people reside in Essa Nagri. The entire respective population comprises of poor and lower middle class, as most of the population works as sweepers, housemaids, laborers in KMC, and sellers.
\end{abstract}

Keywords: civic engagement, socioeconomic conditions, minority, Christian women, case studies, Pakistan.

\section{Introduction}

According to Arnold M. Rose, "A group is a minority group if it is the object of prejudice and discrimination from the dominant groups, and if the members think of themselves as minority" (as quoted in Merton \& Nisbet, 1961: 326).

Massive migration between India and Pakistan took place in 1947. Groups from both countries moved to and from (Stump, 2008), but many stayed where they belonged (Svensson, 2013). It included Muslims in India, as well as Christians and Hindus in Pakistan (Chan, Haines \& Lee, 2014). These are the people who are patriots, as Christians and Hindus chose Pakistan when they had the choice. It is now Pakistan's moral responsibility to respect and work for their welfare (Afzal \& Husain, 1974).

Pakistan has been a part of a multicultural, as well as multi-ethnic Subcontinent. But, now as a minority, they have been invisible (Gopal, 1994). Pakistan's official ideology highly regards its Muslim subjects as compared to minorities (Chitkara, 1996; 1997). As being an Islamic republic, Pakistan deployed socioeconomic aspects encompassing inequality against minorities (Hinduism in Pakistan, 2010). The Constitution of 1973 became discriminatory, as it patronized majorities as being the only valid faith. Minorities like Christians cannot hold any publicly influential administrative as well as major posts (Chitkara, 1997).

(C) Authors. Terms and conditions of Creative Commons Attribution 4.0 International (CC BY 4.0) apply. Correspondence: Dr. Tansif ur Rehman, University of Karachi, Faculty of Social Sciences, Department of Criminology, PAKISTAN. E-mail: Tansif@live.com. 
Pakistan is an Islamic country and the second state in the world after Israel, that came into existence on the justification and basis of religion. According to last census, which was held in 2017, it is a country of approximately 212 million inhabitants, near to $97 \%$ are Muslims. The other 3\% are minorities comprising of different religions. There are mainly seven minorities in Pakistan: (1) Ahmadi, (2) Buddhist, (3) Christian, (4) Hindu, (5) Parsi, (6) Sikh, and (7) Schedule castes.

- Pakistani Christian women are striving against socioeconomic and politico-legal oppression.

- Forced religious conversions of Pakistani Christian women is common.

- Exclusion of Christian women from development plans also exists in Pakistan.

- Lack of opportunities in the democratic participation.

- Non-availability of religious as well as modern education.

- Deprivation of health facilities for Christian women is prevalent in Pakistan.

\subsection{Research objectives}

(1) To find out the civic engagement of Christian women in Pakistan.

(2) To find out the socioeconomic discrimination with Christian women in Pakistan.

(3) To find out the reasons behind Christian women's poor socioeconomic conditions in Pakistan.

\subsection{Background of the study}

According to the U.S. Commission on International Religious Freedom (2018), Pakistan is in the list of blacklist countries, where religious minorities face violence as well as discriminatory behavior. While, the Government of Pakistan has termed this decision as "unilateral and politically motivated" (The New York Times, 2018).

The social and political leadership of Christian community in Pakistan is not much influential and sometimes even self-centered. In normal people's view, Christians are considered as aliens, who might have connections and affiliations with "unfriendly" countries, like the USA and West.

In the case of Pakistan, it is evident that there is a strong need for effective leadership on social grounds for the development of Christian community, especially females. The Christians of Pakistan must be considered loyal and they should enjoy all social as well as economic benefits as compared to their Muslim counterparts. Thus, their civic engagement could enhance the respective development process in Pakistan.

\subsection{Focus of the article}

This research is based on the sociological perspective regarding the civic engagement and socioeconomic challenges of Christian women in Pakistan. Direct as well as indirect efforts have been made in Pakistan to limit the role of minorities. It seems that the majority (Muslims) does not want to give power to the minorities (Christians), in terms of socioeconomic development, especially to Pakistani Christian women.

\subsection{Research questions}

(1) What is the socioeconomic condition of Christian women in Pakistan?

(2) What are the major problems of Christian minority in Pakistan?

(3) What are the general perceptions of Christian women in Pakistan regarding their socioeconomic conditions? 


\subsection{Justification of the study}

This research will provide a new vision for emphasis on the ground realities along with the reasons behind Christian women's poor socioeconomic conditions as well as discrimination based on religion in Pakistan. This information can help to lay down the foundation for primary as well as secondary preventive strategies for the improvement of the respective vulnerable group of women.

\section{Research methodology}

This study focuses on the civic engagement of Christian women in Pakistan. To this end, qualitative research methodology by using five case studies was adopted. Essa Nagri (Karachi), which is the biggest settlement of Christians in Pakistan after Lahore was chosen for this research. This research discusses, explains, and interprets the determinants behind the civic engagement of Christian women in Pakistan and combines the factors incorporated with the causes, patterns, and nature of their weak socioeconomic conditions. That is the very reason, it is explanatory in its very nature.

\section{Discussion}

\subsection{Christians in Pakistan}

According to the Government of Pakistan's Provisional Summary Results of $6^{\text {th }}$ Population and Housing Census - 2017, Pakistan Bureau of Statistics, the Christian community of Pakistan is $1.59 \%$ of the total population. Christians comprise of $1.1 \%$ of rural population and 2.59\% of urban population of Pakistan.

\subsection{Christians in Karachi}

Karachi has the second largest number of Christians after Lahore in Pakistan. Unfortunately, no official records are available. Christian activists estimate this figure to be around o.8 million (Rehman, 2017). While, the leader of the Protestant church (Sindh), Bishop Sadiq Daniel, claimed that there are about one million Christians in Karachi (Craig, 2015).

Enlisted are the biggest settlements (number wise) of Christians in Karachi: (1) Essa Nagri, (2) Manzoor Colony, (3) Akhtar Colony, (4) Azam Basti, (5) Pahar Ganj, (6) Khuda Ki Basti, (7) Ittehad Town, (8) Michael Town, (9) Christian Town, (10) Mariam Colony, (11) Saddar, (12) Father's Colony, and (13) Grax Colony.

There are 110 churches in Karachi and all of them have sizeable congregations (The News International, 2017). More than 90\% of Christians in Karachi speak Punjabi. Most of the Christians migrated to Karachi in 1965 from Kasur, Sialkot, as well Narowal districts of province Punjab (Craig, 2015).

Mainly, Christians in Punjab before migrating to Karachi were involved in the agrarian sector. Now, in Karachi they work in municipality, industries, education sectors, as well as health sectors (Craig, 2015). In Karachi, which is a cosmopolitan city of more than 14.9 million inhabitants, the total population of Christian community is $2.42 \%$ (Hasan \& Mohib, 2009).

The Christian community is so assimilated within the culture of Pakistan that it is difficult to recognize them as Christians (Curtis \& Mullick, 2009). In the past, the Muslims and Christians showed respect for each other's religious places. But, with the passage of time, the situation has changed (Sabri, 1994). 
In the past, Christian community was well-off and had good businesses and jobs. Now, they have become poor and a clear majority is even living below the poverty line. Most of the Christians are engaged in sanitary work in different government sectors and private institutions.

The Christian women in Essa Nagri, Karachi's Christian neighborhood, has a Christian population of over 40,000 (Agenzia Fides, 2014). Christian women are more vulnerable to the prevailing socioeconomic structure. Thus, the leading trends of discrimination in the society have hindered Christian women to actively participate in the development process.

Christians at all levels are unfortunately facing discrimination. They live as a secondclass citizen in Pakistan. While, the women who belong to this minority group are facing double discrimination, firstly as a woman, and then as a Christian.

\section{Case studies}

\subsection{A nurse}

Ms. Sara is a 25-year lady. She has completed her Intermediate (12 ${ }^{\text {th }}$ standard) education as a private (external) candidate along with a nursing diploma. She lives with her parents and belongs from the middle class. She represents the middle class and educated family.

She is engaged in her own community and is going to get married soon. She said that, they can't marry out of their community, but there are no such restrictions on girls' education and other social activities. She received full support from her family and community members during her education, but she lost interest in education after completing her Intermediate and nursing diploma.

She shared that, "During my entire educational experience, I never faced any discriminatory behavior from my Muslim fellows, as they were always very humble towards me and other non-Muslims students. But, I do remember the behavior of one of my class teacher. She was our Islamic Studies teacher, and taught ethics to the non-Muslim students. She was quite rude during the teaching and sometimes gave us severe punishment, even just for the nominal mistakes. She always uses to grade us with very low marks in the class tests".

She also shared, "I guess no religion teaches us discrimination and injustice. It all depends on people's perception and the unawareness about their very own religion". She further added that, "If the Christian community in Pakistan really wants to improve their daily lives, they have to educate their women as much as possible. Because, education is the only key to develop the Christian community in Pakistan”.

As far as women remain uneducated and unaware, the real process of prosperity and development couldn't be started in any community, especially in the context of Essa Nagri (Karachi), where every girl and boy need education and awareness regarding the constructive social changes that are prevalent globally.

\subsection{A retired KMC employee}

Mrs. Alina Yusuf is a 62-years-old widow and a retired KMC worker. She has worked 27 years as a laborer in the Engineering Department of KMC. She had nine children, out of which two passed away, while three boys and four girls survived. She lives in a small two room house with her family.

After her retirement, her elder son was adjusted in the seat vacated by her, while her other children are jobless. All her daughters have been married. She shared that, her house is very old and damaged; therefore, the KMC authorities have issued her a notice to vacate the house 
immediately, as it can lead to any serious incident, but she is still living there, because she doesn't have any other option.

She added, as in KMC department most of the employees at lower level jobs, such as sweepers, laborers, and other small jobs are non-Muslims. They are working without any health care facility or other benefits. But, still they are not getting their salaries, which have been the cause for dropout of many children from the schools, especially girls. Because, parents can only afford to pay their sons fee, because it is a traditional thinking that boys will be the bread earner for their family in future, while the girls will settle down in other's house after their marriage.

She further said that, for decades her community has been living in the same condition. She doesn't feel any positive change among the people of the respective community. In fact, young boys and girls of the area are getting more and more vulnerable each day due to lack of awareness, education, access to information, and media's influence. Therefore, their general interest is towards watching movies, smoking, drinking, and flirting with the girls.

She also highlighted the issue of early marriages of girls in the respective community. She continued, "Due to the indecisive local environment girls get married between the ages of 16 to 22 years, and become mother in early age, so they could not play their vital role in any socioeconomic activities for the community, which is an unfortunate scenario."

\subsection{A Case of early marriage}

Mrs. Javeria is an 18-years-old girl and got married when she was only 15 years. She has a two-year-old daughter, and is a simple housewife living with her in-laws. Her husband, Mr. Yasir, is 26 years old and works in a garment factory as a laborer.

Mrs. Javeria has studied till $5^{\text {th }}$ standard, because of the cultural constraints and traditional oppression. Her family was highly male dominated, and the general opinion regarding girls' education is that, girls have to settle down with their in-laws after marriage, so there is no such need to invest in their education.

She also shared that, around three years ago, four girls of her community, i.e. Catholic, eloped with the boys from the other sect, i.e. Protestant, as simply they could not marry out of their sect because of the established norms. The respective girls belonged to Catholic sect of Christianity, which is comparatively more religious than Protestants in Pakistan. Their living style and culture is also different, as the males from the Protestant sect use to drink, smoke, and are also involved in domestic violence.

She added that, "Seven months ago, a girl took poison and died, because their parents did not agree for their inter-sect marriages. She was also from my sect and was only 17-years-old". She also revealed that, two years ago a girl named Nazia from Essa Nagri also converted into Islam and married to a Muslim boy. She never returned, as nobody knows where she is or what has happened with her, whether she is even alive or not. After this incident, her parents left this area and migrated to Canada because of the defamation.

She explained that, because of all such incidents, her community members have decided to marry off their daughters as early as possible, which she thinks is one of the obstacles in the prospective development of Christian females in Pakistan. She is one of the various examples of this dilemma, while she was not ready for the marriage at the age of 15 and even wanted to continue her education at the school, but she never got permission for it and later she was forced to marry.

She also shared that her husband is very loving and caring, but her father-in-law is quite strict regarding the old traditional values and religious observance. She is only permitted to go outside with her husband and mother-in-law. She is not allowed to wear pant shirt, and can 
only wear "Shlawar Qamez" (Pakistani traditional dress), as her father in-law doesn't allow it. She also covers her face in front of her father-in-law and brothers-in-law. She expressed that in her community there are various restrictions and limitations regarding the social activities of the women. All important matters are decided by men, and as a result the women are living in a miserable condition in Pakistan.

\subsection{A housemaid}

Mrs. Sonia is a 32-year-old lady and a housewife searching for the job. She is married to Mr. David, a Karachi Water and Sewerage Board (KWSB) worker. She had four children, a girl and three boys, but one of her son died just after a few months of the birth. She is living in a one room house, which has only a bed, TV, and few crockery items.

She studied till middle ( $5^{\text {th }}$ standard), and left school after her mother's death. She got married when she was 17 years old. After her marriage, she has worked temporarily as a sweeper in Ibn-e-Sina Hospital, and several houses. Currently, she is unemployed and searching for a new job.

She said, "My husband is not getting his salary for the last two months, therefore we had to take out our children from the school. There is only one school in our area, which has the capacity to accommodate only 70 to 80 students, because of the existing faculty of five teachers. All these teachers come from different areas of the city and the educational quality of this school is not satisfactory, because no government official has visited this school since long. Teacher absenteeism, lack of interest, discipline, damaged furniture, and unfurnished classrooms are the major issues of this school".

She added that, she is very fond to send her daughters to the school and that's why she is looking for a job. It's very difficult to get a permanent job, and she always have been appointed for a very short term (i.e. three to four months) until the employer could get a better employee. Most of the people are reluctant to appoint a Christian at their houses for the domestic work.

She also shared that, while she was working as a housemaid, her salary was PKR 5,O0O (approximately US\$ 36) per month for washing clothes, dusting, mopping, etc. as people don't prefer her to clean their plates and dishes, and her cup, plate, and glass were kept separate.

\subsection{A housewife}

Mrs. Danial is a 45-year-old housewife and belongs to Christian community. She lives in a small house which consists of two rooms, with her husband and three children (two girls and a boy). She belongs to an indigenous family of the city, because her ancestors have been living in Essa Nagri even before the partition of the Subcontinent.

The husband of Mrs. Danial, Mr. Danial Saleem is the only bread earner of the family. He works in Karachi Municipal Corporation (KMC) as a sanitary worker. Mrs. Danial's only son has studied till matriculation ( $10^{\text {th }}$ standard), and her two daughters have completed only primary ( $5^{\text {th }}$ standard) education.

She doesn't have enough financial resources to support their further studies, but she is willing to send at least her son to college and even to the university for higher education. So, they could get better employment opportunities and not end up in working as a sanitary worker or performing other less prestigious jobs.

She said that, when she was young, she was not allowed to attend the school from her elders, and still in her family girls' education is not supported by the male members. She has worked hard to get permission to send her daughters to school, but now it's very difficult to acquire 
permission to send them to college and university. Because, the social dynamics of the respective locality are insalubrious. Vagabonds pass amusing remarks on girls and eve-teasing is very common.

She added that, in the last three years, some girls of her community scuttled with the local boys and later got married to them, therefore education is not encouraged in her community, especially for girls. Moreover, criminal activities are also one of the various hurdles in girls' education and their employment.

She explained that the male dominance and lack of awareness among the masses are the main hurdles in the development of the women in her community. She said, "I am a witness of my whole life's personal experience. I have never faced any kind of discriminatory behavior from the Muslim community, and they never treated me as a lower citizen on the basis of my religion".

She also shared that, "There is an urgent need for the awareness program for both of the sexes, and we need to engage youth in constructive activities, so they can get busy in their own activities and girls may feel free to step outside their houses. This way they can acquire education and play their effective role in the society for the development of Pakistan".

\section{Analysis of case studies}

The respondents have very small accommodations and are usually engaged in lower level jobs, such as sweepers and laborers, working without any health care facility or other benefits. They also complained about low salaries and the high unemployment rate. The majority of the people are reluctant to appoint a Christian at their houses for the domestic work, as they don't prefer them to clean their plates and dishes, even the utensils for Christian workers are kept separate.

Low education of both the sexes, especially females is a serious problem as the respondents have a firm believe that education is the only key to develop their community. High school dropout ratio and the presence of a single school in the vicinity, along with teacher absenteeism, lack of interest, damaged furniture, and unfurnished classrooms are the major obstacles in this sphere.

The respective respondents also shared that some girls eloped with the local boys and later got married to them as simply they could not marry out of their caste because of the established norms. Because of this aspect, there have also been several suicide attempts.

The respondents also complained about the abundance of vagabonds as well as eveteasing along with other criminal activities at the community level, i.e. drugs usage and alcohol consumption. Moreover, early marriages, large families, male dominance, and lack of awareness are the hindrances in the civic engagement and socioeconomic development of Christian community in Pakistan.

\section{Conclusions}

There are few middle-class Christians in professional fields. As, it is difficult for them to join Government institutions and especially the Armed Forces in Pakistan. While, the Christian elite class enjoys good relations with the majority, but there is still non-availability of religious education and training centers for the Christian community across Pakistan.

Essa Nagri, Karachi, represents the largest population of Christian community in Pakistan, and it is one of the oldest localities in the city. Pakistani Christian women are striving 
against problems, like political and social oppression, gender and religious discrimination, forced conversions, exclusion from development plans, lack of opportunities in the democratic participation, as well as non-availability of religious education.

The community members of Essa Nagri are completely deprived of health facilities, as there is no dispensary, maternity center, and other community health care centers. Most of the community members, and especially the females have only access to only three governmental hospitals of Karachi which are in devastating conditions. They can consult with private doctors if they can afford it. While, a few people of this area can really afford private doctors. The education sector is also in a devastating scenario, as there is only one government school in Essa Nagri.

The streets in the colony are almost damaged and broken. Open manholes can be seen everywhere, and the people are living below the poverty line, i.e. without any basic facilities, such as access to clean drinking water, proper sanitation system, frequent power failures, etc. The past as well as the existing government has not played its role effectively, and Christian women are experiencing a very tough time.

\section{Recommendations}

(1) The Government of Pakistan must take constructive initiatives regarding the upheaval of women of minorities.

(2) Christian politicians, religious leaders, and scholars must strive for the socioeconomic development of the masses. development.

(3) The media should represent the important role of Christian minority in Pakistan's

(4) The media should highlight the problems faced by Christian women in Pakistan.

(5) Full participation of minorities to be ensured in all spheres of life, as they should be provided with equal opportunities.

(6) The Christian community must try to establish their own education, medical, and other developmental institutions with the help of government, philanthropists, and professional donors.

(7) NGOs and civil society groups should raise awareness about the women's sociocultural as well as religious norms, along with the rights accorded by the Constitution of Pakistan.

(8) Christian women's due share in family property must also be ensured, so that their socioeconomic status is enhanced.

(9) Forced conversions and child marriages along with forced marriages should be dealt strongly by the Government of Pakistan. government.

(10) Education for minorities, especially for females should be ensured by the

(11) The minority quota should be raised in government jobs, and extra seats should be allocated for the women of the minorities.

(12) Unfortunately, the behavior of some Muslims towards the Christian minority is not appreciable. Religious scholars must play their vital role in guiding them to abstain from any hatred or prejudice.

hazards.

(13) Safety equipment to be provided to protect Christian women from occupational Pakistan.

(14) Wages should be increased to ensure a prosperous life for Christian women in 


\section{Acknowledgements}

This research did not receive any specific grant from funding agencies in the public commercial, or not-for-profit sectors.

The author declares no competing interests.

\section{References}

Afzal, M., \& Husain, M. (1974). The population of Pakistan. Lahore, Pakistan: Ferozsons.

Agenzia Fides. (2014). Terrorist groups settle in the Christian area of Essa Nagri in Karachi. Retrieved from http://www.fides.org/en/news/36013-

ASIA PAKISTAN Terrorist groups settle in the Christian area of Essa Nagri in Kar achi\#.WIToitJ970w.

Chan, Y. W., Haines, D., \& Lee, J. (2014). The age of Asian migration: Continuity, diversity, and susceptibility (Vol. 1). Newcastle, UK: Cambridge Scholars Publishing.

Chitkara, M. G. (1996). Mohajir's Pakistan. New Delhi, India: APH Publishing Corporation.

Chitkara, M. G. (1997). Human rights in Pakistan. New Delhi, India: APH Publishing.

Craig, T. (2015). Karachi's downtrodden Christians get a towering if contentious symbol of hope. Washington Post (19 May). Retrieved from https://www.theguardian.com/world/2015/may/19/karachi-cross-crucifix-christiansmuslims-pakistan.

Curtis, L., \& Mullick, H. (2009). Reviving Pakistan's pluralist traditions to fight extremism (4 May). The Heritage Foundation. Retrieved from https://www.heritage.org/asia/report/revivingpakistans-pluralist-traditions-fight-extremism.

Gopal, R. (1994). Hindu culture during and after Muslim rule: Survival and subsequent challenges. New Delhi, India: M.D. Publications Pvt. Ltd.

Government of Pakistan (2017). Provisional Summary Results of $6^{\text {th }}$ Population and Housing Census - 2017. Pakistan Bureau of Statistics. Retrieved 29 November 2018, from https://bytesforall.pk/.

Government of Pakistan (2018). The Constitution of 1973. Retrieved November 11, 2018, from http://www.pakistani.org/pakistan/constitution/.

Hasan, A., \& Mohib, M. (2009). Urban slums reports: The case of Karachi, Pakistan. Retrieved from http://www.ucl.ac.uk/dpu-projects/Global Report/pdfs/Karachi.pdf.

Hinduism in Pakistan (2010). Enid, OK: Books LLC.

Karachi's Christian community - the beauty of diversity. (2017, July 3). The News International. Retrieved from https://www.thenews.com.pk/print/213957-Karachis-Christian-community-thebeauty-of-diversity.

Merton, R. K., \& Nisbet R. A. (1961). Contemporary social problems: An introduction to the sociology of deviant behavior and social disorganization. California: Harcourt, Brace \& World.

Rehman, Z. U. (2017). Christians strive for 'proper' count this time round. The News International (13 February). Retrieved from https://www.thenews.com.pk/print/185811-Christians-strive-forproper-count-this-time-round.

Sabri, M. H. K. (1994). The culture and society of Pakistan. Lahore, Pakistan: Publishers Emporium.

Stump, R. W. (2008). The geography of religion: Faith, place, and space. Lanham, MD: Rowman \& Littlefield Publishers. 
T. ur Rehman - Civic Engagement of Christian Women in Pakistan

Svensson, T. (2013). Production of postcolonial India and Pakistan: Meanings of partition. Abingdon, UK: Routledge.

The Associated Press (2018). Pakistan rejects downgrading by US in religious freedom (11 December). The New York Times. Retrieved from

https://www.nytimes.com/aponline/2018/12/11/world/asia/ap-as-pakistan-us-religiousfreedom.html.

... (2018). US adds Pakistan to blacklist for religious freedom violations (11 December). Dawn. Retrieved from https://www.dawn.com/news/1450827. 